
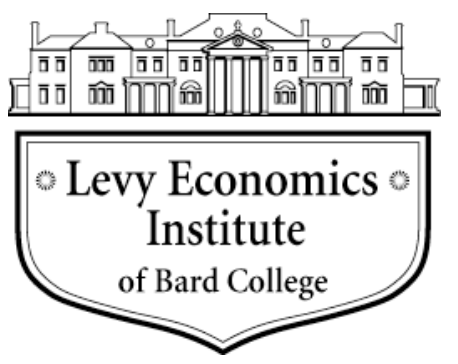

Working Paper No. 701

\title{
Women, Schooling, and Marriage in Rural Philippines
}

by

Sanjaya DeSilva

Levy Economics Institute of Bard College

\author{
Mohammed Mehrab Bin Bakhtiar \\ Bard College
}

December 2011

The Levy Economics Institute Working Paper Collection presents research in progress by Levy Institute scholars and conference participants. The purpose of the series is to disseminate ideas to and elicit comments from academics and professionals.

Levy Economics Institute of Bard College, founded in 1986, is a nonprofit, nonpartisan, independently funded research organization devoted to public service. Through scholarship and economic research it generates viable, effective public policy responses to important economic problems that profoundly affect the quality of life in the United States and abroad.

Levy Economics Institute

P.O. Box 5000

Annandale-on-Hudson, NY 12504-5000

http://www.levyinstitute.org 


\begin{abstract}
Using data from the Bicol region of the Philippines, we examine why women are more educated than men in a rural, agricultural economy in which women are significantly less likely than men to participate in the labor market. We hypothesize that educational homogamy in the marriage market and cross-productivity effects in the household allow Filipino women to reap substantial benefits from schooling regardless of whether they enter the labor market. Our estimates reveal that the return to schooling for women is approximately 20 percent in both labor and marriage markets. In comparison, men experience a 12 percent return to schooling in the labor market. By using birth order, sibship size, percent of male siblings, and parental education as instruments, we correct for a significant downward bias that is caused by the endogeneity of schooling attainment.
\end{abstract}

Keywords: Returns to Education; Gender; Marriage; Philippines

JEL Classifications: I21, J12, J16, J24, O15 


\section{INTRODUCTION}

Reducing gender differences in educational attainment has long been a priority of development economists and policymakers (see King and Hill 1993; Alderman and King 1998 for reviews). As the United Nations declared in the Millennium Development Goals, eliminating gender disparity in education is widely acknowledged as a key instrument for promoting gender equity and empowering women (United Nations 2010). Throughout the developing world, numerous interventions on the cost-side have been implemented (Hill and King 1995; King and Lillard 1987). ${ }^{1}$ However, gender schooling gaps are likely to persist as long as economic benefits from the education of girls remain low. Although much of the empirical literature on gender differences in returns to schooling has focused on countries where girls lag behind, policy insights can be gained by taking a closer look at the handful of developing countries that have eliminated the gender schooling gap. This paper presents an analysis of the benefits to female schooling in the Bicol, a rural, impoverished, and predominantly agricultural region of the Philippines in which women are more educated than men.

There is a consensus in the literature that private returns to schooling are higher for women than for men in the Philippines (Sakellariou 2004, Quisumbing, Otsuka and Estudillo 2004). Schooling increases the labor force participation rate for women but not for men; this partly explains why women experience higher returns unconditional on labor force participation. Conditional on labor force participation, higher returns for females are often attributed to the relatively large gender earnings gap in favor of men at low levels of education which progressively narrows with education (Sakellariou 2004). However, the connection between high private returns at the individual level and high school attainment is not automatic. In societies with income pooling at the household level and low levels of female labor force participation, female educational attainment can be low even in the presence of high labor market returns if non-earned income is not responsive to schooling attainment. Specifically, if non-earned income is substantially higher than own income at low levels of schooling, and if non-earned income is independent of schooling, the household level income-schooling profile

\footnotetext{
${ }^{1}$ Some innovative examples are the provision of targeted cash transfers which are conditional upon attendance and performance, reduction of the distance to schools through school construction in areas where social norms discourage girls from commuting long distances, and investments in alternative energy and water sources in areas where female child labor is used extensively for gathering firewood and water (See, for example, UN Department for Public Information 2010).
} 
can exhibit non-convexities which may lead to multiple equilibria and the possibility of low investments in schooling for female children. Such non-convexities would be minimized and high schooling attainment levels would result if female labor force participation rates are sufficiently high, or if schooling has a sufficiently large causal effect on non-earned income.

In this paper, we examine whether there are sufficiently large household-level pecuniary returns to schooling for Filipino women through the association of schooling with spousal earnings. There are two channels at work: 1) In a marriage market such as that of the Philippines, where (for cultural, religious, and historical reasons) educational homogamy is prevalent, schooling increases the likelihood of marrying a spouse with high income (Welch 1974); 2) schooling of women — even when they do not participate in the labor market—can enhance the labor market productivity of spouses and other family members through the exchange of ideas, mutual learning, and intra-household specialization (Benham 1974).

Although such household-level pecuniary returns are particularly important for women in societies such as the Philippines where cultural and other institutional constraints limit their participation in the formal labor market, a vast majority of studies of returns to schooling in developing countries has followed the original Mincerian setup of relating schooling to wage income at the individual level (Jolliffe 2002). By examining the causal relationship between schooling and spousal earnings, this paper contributes to a literature which-barring a handful of exceptions (Scully 1978; Tiefenthaler 1997; Huang et al. 2009)— has not focused on developing countries. The Philippines is a particularly interesting case study because a relatively traditional and gender segregated labor market coexists with a relatively egalitarian and individual choice-based marriage market in which educational homogamy is widely observed.

Our data come from the 1983 and 2003 waves of Bicol Multipurpose Survey conducted in the Camarines Sur province in the Bicol region at the southern tip of the Luzon island. ${ }^{2}$ We examine marriage and labor market outcomes in 2003 of the children of households originally surveyed in 1983. The sample is limited to adult children who were of working age (20 to 60) in 2003. With data spanning two decades, we are able to relate adult outcomes of our subjects with attributes of the family in which they were raised. Specifically, the availability of detailed information on the sibship structure and parental background of the original households of currently married adults provides us with instrumental variables to identify the causal effect of

\footnotetext{
${ }^{2}$ For more information on the survey, see Bicol River Basin Development Program (1983), Lanzona (1994) and DeSilva (2011).
} 
schooling attainment on spousal earnings. To our knowledge, only two other studies have identified this causal effect in developed or developing countries (Lefgran and McIntyre 2006; Huang et al. 2009).

The remainder of the paper is organized as follows: The second section presents evidence that schooling attainment is higher for women than for men, and discusses several explanations which have been offered in the literature. The third section examines the relationship between schooling, labor force participation and own earnings, and reviews the literature which documents relatively high private returns for Filipino women. The fourth section discusses the theoretical basis and empirical evidence for educational homogamy and the positive association between schooling and spousal earnings. The fifth section presents the econometric model and discusses the identification strategy. The sixth section presents and discusses the results of an interval regression model which corrects for sample selectivity and endogeneity of schooling. Our results reveal that Filipino women experience returns to schooling of about 20 percent in both labor and marriage markets. This is substantially larger than the labor market return of about 12 percent for Filipino men. The high returns in both labor and marriage markets help explain why the gender schooling gap does not exist in the Bicol, even though almost half of adult women are not in the labor force. The seventh section presents results of specification tests which confirm that our instrumental variables are relevant and valid. The eighth section concludes by highlighting the key findings and discussing policy implications.

\section{GENDER AND SCHOOLING}

In our sample, women spend 0.64 years more, on average, in school than men (Table 1). This difference in means can be traced to gender differences at the two ends of the schooling distribution. Women are 4.69 percent more likely to be college educated, and 5.98 percent less likely to have only an elementary education. This pattern is consistent with those reported in earlier studies. In a study of three generations, Quisumbing, Otsuka and Estudillo (2004) report 10 years of average schooling for girls and 8.5 years for boys in the youngest generation. They also find that the female advantage is relatively recent; in the middle generation, both genders have 6.2 years of schooling-whereas in the oldest generation, males are more educated with 3.7 years of schooling compared to 3.2 years for females. Sakellariou's (2004) sample contains 
even larger differences, with 39 percent of women reporting a college education (compared to 15 percent of men) and only 22.5 percent of women reporting a primary education or less (compared to 32 percent of men).

Table 1: Educational Attainment by Gender

\begin{tabular}{|l|l|l|l|}
\hline & Female & Male & Both \\
\hline No Schooling (\%) & 11.200 & 11.690 & 11.450 \\
\hline Elementary (\%) & 32.350 & 38.390 & 35.480 \\
\hline Secondary (\%) & 33.270 & 32.120 & 32.670 \\
\hline Some College (\%) & 10.940 & 10.260 & 10.580 \\
\hline College Graduate (\%) & 12.250 & 7.550 & 9.810 \\
\hline $\begin{array}{l}\text { Mean years of } \\
\text { schooling }\end{array}$ & 9.128 & 8.493 & 8.792 \\
\hline
\end{tabular}

The educational advantage of women is relatively smaller in the Bicol compared to other parts of the Philippines. However, the fact that educational outcomes favor women at all in a relatively poor and agricultural region where the predominant occupation of rice farming has traditionally favored men is a striking reflection of the educational achievements of Filipino women. Although Southeast Asia is generally more similar to East Asia, Latin America, and Europe than to Sub-Saharan Africa and South Asia in terms of gender equity in education, the case of the Philippines is exceptional even by the region's standards. ${ }^{3}$

Gender differences in educational outcomes are typically attributed to gender differences in returns to schooling (due to differences in costs and expected benefits), gender-specific intergenerational transfer patterns, or the interplay of resource constraints and parental preferences for sons (Alderman and King 1998). The absence of an educational gender gap in the Philippines is partly attributable to an educational system which has generally succeeded in providing girls with equal access and to familial institutions that are relatively egalitarian toward girls. For example, Quisumbing, Otsuka and Estudillio (2004) highlight egalitarian parental preferences which allocate proportionately more schooling to daughters to compensate for the larger land inheritances given to sons. There is also evidence that schooling benefits women and their families through their contributions to non-market home production activities, especially with regards to education and health of children (Haverman and Wolfe 1984; Hill and King

\footnotetext{
${ }^{3}$ In Indonesia, for example, a modest gender gap in schooling in favor of males has been documented (Deolalikar 1993).
} 
1995). Similarly, the contribution of women's schooling to the family farm or enterprise has been documented (Jolliffe 2002) even though the evidence of this is limited in the Philippine rice farms (Estudillo, Quisumbing and Otsuka 2001a; Estudillo, Quisumbing and Otsuka 2001b).

\section{SCHOOLING AND THE LABOR MARKET}

The educational gains made by Filipino women are not reflected in corresponding gains in labor force participation; as in many other developing (and some developed) countries, women are considerably less likely to participate in the labor market. In our sample, only 56 percent of females engage in non-household work compared to 86 percent of men (Table 2). However, with education, the labor force participation rate increases markedly for females; 76 percent of college educated women work in the labor market compared to just 46 percent of women with at most an elementary school education. In contrast, the labor force participation rate of men does not vary systematically with educational attainment.

Conditional on employment, there is an earnings advantage for women; almost 30 percent of working women earn 30,000 pesos or more compared to fewer than 20 percent of the working men (Table 2). The mean earnings of college educated women are approximately $20 \%$ higher than that of college educated men. On closer inspection, we see that the earnings advantage of working women is confined largely to those with a college degree. At lower levels of schooling, earnings of women are lower on average and more variable than that of men; women are over-represented at both tails of the earnings distribution. 
Table 2: Labor Force Participation and Income by Education Level and Gender 4

\begin{tabular}{|c|c|c|c|c|c|c|c|c|c|}
\hline \multirow[b]{2}{*}{ Females } & \multicolumn{6}{|c|}{$\begin{array}{l}\text { Cumulative Frequency in Income Categories (in pesos) } \\
\text { by Education Level }\end{array}$} & \multirow[t]{2}{*}{$\begin{array}{l}\text { Mean } \\
\text { Income }\end{array}$} & \multirow[t]{2}{*}{$\begin{array}{c}\text { Median } \\
\text { Income } \\
\text { Range }\end{array}$} & \multirow[t]{2}{*}{$\begin{array}{l}\text { LFP } \\
\text { rate }\end{array}$} \\
\hline & $\begin{array}{l}\text { Under } \\
6,000 \\
\end{array}$ & $\begin{array}{l}6,000- \\
14,999 \\
\end{array}$ & $\begin{array}{c}15,000- \\
29,999 \\
\end{array}$ & $\begin{array}{c}30,000- \\
59,999 \\
\end{array}$ & $\begin{array}{r}60,000- \\
99,999 \\
\end{array}$ & $\begin{array}{l}100,000- \\
199,000 \\
\end{array}$ & & & \\
\hline Elementary & 21.210 & 39.390 & 64.840 & 84.230 & 90.290 & 94.530 & 15749.950 & $\begin{array}{l}15,000- \\
29,999\end{array}$ & 0.462 \\
\hline Secondary & 13.250 & 27.350 & 52.560 & 79.480 & 89.740 & 93.590 & 21599.560 & $\begin{array}{l}15,000- \\
29,999 \\
\end{array}$ & 0.545 \\
\hline Some College & 5.880 & 18.820 & 47.060 & 64.710 & 82.360 & 90.600 & 28574.095 & $\begin{array}{l}30,000- \\
59,999 \\
\end{array}$ & 0.603 \\
\hline $\begin{array}{l}\text { College } \\
\text { Graduate }\end{array}$ & 5.300 & 11.360 & 20.450 & 41.660 & 68.180 & 93.180 & 47939.402 & $\begin{array}{l}60,000- \\
99,999 \\
\end{array}$ & 0.763 \\
\hline All & 12.660 & 25.970 & 48.210 & 70.610 & 84.250 & 93.340 & 24716.352 & $\begin{array}{l}30,000- \\
59,999 \\
\end{array}$ & 0.564 \\
\hline \multicolumn{10}{|l|}{ Males } \\
\hline Elementary & 10.370 & 30.880 & 56.460 & 88.490 & 94.940 & 97.010 & 18299.780 & $\begin{array}{l}15,000- \\
29,999 \\
\end{array}$ & 0.866 \\
\hline Secondary & 10.950 & 27.620 & 48.570 & 84.520 & 95.470 & 98.570 & 20144.657 & $\begin{array}{l}30,000- \\
59,999 \\
\end{array}$ & 0.888 \\
\hline Some College & 2.480 & 13.220 & 27.270 & 64.460 & 89.250 & 94.210 & 32729.909 & $\begin{array}{l}30,000- \\
59,999\end{array}$ & 0.795 \\
\hline $\begin{array}{l}\text { College } \\
\text { Graduate }\end{array}$ & 6.060 & 18.180 & 26.260 & 50.500 & 73.730 & 90.900 & 40289.657 & $\begin{array}{l}30,000- \\
59,999 \\
\end{array}$ & 0.854 \\
\hline All & 9.310 & 26.440 & 47.300 & 80.730 & 92.550 & 96.740 & 22049.530 & $\begin{array}{c}30,000- \\
59,999 \\
\end{array}$ & 0.858 \\
\hline
\end{tabular}

The picture that emerges from the earnings distributions is that of a segmented labor market where women reap returns to schooling in the labor market only if they acquire high levels of education such as a college degree, and find employment at the high end of the earnings distribution. A large number of women who do not reach the top of the schooling or earnings distribution are concentrated in low earning occupations. Many such women appear to stay out of the labor force altogether, as evidenced by the high correlation between educational attainment and the labor force participation rate.

\footnotetext{
${ }^{4}$ In our survey data, earnings are reported in categories: 1) less than 6,000; 2) 6,000-14,999; 3) 15,000-29,999; 4) 30,000-59,999; 5) 60,000-99,999; 6) 100,000-199,000; 7) 200,000-299,999; and 8) 300,000 and above (all in pesos). Due to the lack of sufficient observations, we have combined the sixth and seventh categories. This last combined category (200,000 and above) is not listed in Tables 2 and 3 since the cumulative frequency for the highest category is always 100 percent.
} 
Previous studies have documented generally high earnings prospects for women, especially for those with high levels of education. In Trostel, Walker, and Woolley’s (2002) estimates, labor market returns to education are much larger for women (19.2 percent) than for men (11.3 percent). In the rural Bicol region where our study’s villages are located, Lanzona (1998) reports that returns to schooling are the same or slightly higher for females compared to males. Quisumbing, Otsuka and Estudillo (2004) argue that women benefit from schooling more than men because returns to schooling are larger in non-farm sectors, and a large proportion of employed women are engaged in non-farm work. Although women are consistently underpaid relative to their schooling endowments (more than 30 percent), the wage discount is much higher for low earnings workers and decreases progressively as you move up the earnings distribution (Sakellariou 2004). Demand for female labor is relatively low in low-skilled "blue collar” jobs due to institutionalized patterns of occupational segregation, and also because of the physical labor requirements of many low-skilled jobs. With schooling, women face a more level playing field and are better able to overcome discrimination and occupational segregation. In addition, average skill level of highly educated female workers is often higher than that of their male counterparts because, at any level of schooling, the threshold skill level at which women choose to participate in the labor market is higher. The coexistence of lower average wages and higher (or similar) returns to schooling for women has been observed in countries as varied as Indonesia (Behrman and Deolalikar 1995), Guinea (Glick and Sahn 1997) and Peru (King 1996). However, women are typically less educated than men in these countries due to gender earnings gaps and other social, cultural, and institutional factors which keep many women out of the labor force. Women who have resources_-both financial and intellectual — to attain high levels of education and to obtain professional jobs will acquire high levels of schooling whereas those without such resources will plan to stay out of the labor force and have consequently little or no labor market motivations to acquire high levels of schooling. Multiple equilibria could emerge concentrating educational attainment among females from wealthier families and limiting the potency of education as an instrument of economic mobility.

To understand why there is gender parity in education when a large proportion of women do not work outside of home, the contribution of women's schooling to household outcomes other than wage earnings must be considered. There is substantial evidence, for example, that female education has a strong effect on the health, nutritional, and educational outcomes of children (Haveman and Wolfe 1984). The goal of this paper is to test whether the 
education of Filipino girls has a causal effect on their future well-being through the marriage market rather than the labor market. Because the Philippines has a marriage market which is similar to that of Western European and Latin American societies and a labor market that is more representative of the developing countries of Asia, the Philippine case provides us with an interesting opportunity to study how educational investments in girls are influenced by marital institutions which promote complementarity, self-selection, and homogamy in the context of a developing economy.

\section{SCHOOLING AND MARRIAGE}

Following the seminal work by Benham (1974), several studies have established a positive correlation between schooling and spousal earnings in a variety of countries (Wong 1986; Grossbard-Shechtman and Neuman 1991; Huang et al. 2009). Benham's hypothesis of a positive correlation is consistent with the exchange theory of marriage (Becker 1973; Becker 1974) only if schooling improves non-market productivity of women and facilitates greater specialization within the marriage. Cross-productivity gains (from one spouse's human capital to the other's productivity) emerge when married couples share ideas and learn from each other (Wong 1986; Jepsen 2005; Groothuis and Gabriel 2010). Such complementarities between the spouses are particularly salient in environments such as rural areas in developing countries, where households are engaged in joint production and entrepreneurial activities. For example, Wong (1986) finds in Taiwan that cross-productivity effects are stronger in entrepreneurial families where spouses engage in joint production. The presence of cross-productivity effects is also consistent with the finding in a large number of studies that married men have higher individual earnings than unmarried men (Kenny 1983; Loh 1996).

An alternative hypothesis is that the correlation between schooling and spousal earnings emerges from assortative mating in the marriage market (Welch 1974; Grossbard-Shechtman and Neuman 1991; Liu and Zhang 1999; Huang et al. 2009). Although negative assortative mating (heterogamy) based on intra-household specialization is consistent with the exchange theory of marriage (Becker 1973; Becker 1974; Becker 1981; see Olsen 2008 for review) and is supported by some empirical studies (Zimmer 1996; Zhang and Liu 2003), much of the evidence - primarily from advanced industrial economies — has pointed to the existence of positive assortative mating or homogamy (Mare 1991; Loh 1996; Brien 1997; Qian 1998; 
Pencavel 1998). ${ }^{5}$ When schooling enhances both market and non-market productivity, the exchange model can explain homogamy with respect to education but not to earnings since specialization in educationally homogamous marriage leads to high labor market earnings for the husband and lower likelihood of labor force participation for the wife (Pencavel 1998). Lam (1988) provides an alternative theoretical foundation for positive assortative mating based on the joint consumption of household level public goods. More broadly, homogamy is generally associated with the complementarity of the spouses rather than with exchange or specialization (Olsen 2008; Groothuis and Gabriel 2010). ${ }^{6}$

In many developing countries, especially those in sub-Saharan Africa, the Middle East, North Africa, and South Asia, marriages continue to be arranged by families and are often based on economic considerations; such marriages are more likely to follow a negative assortative mating pattern which is consistent with intra-household specialization. Two examples are the custom of men "marrying down” observed in countries such as Japan, Korea, and Singapore (Olsen 2008) and the arranged marriages of South Asia and sub-Saharan Africa where the exchange motive and specialized gender roles are institutionalized through customs such as the dowry or bride price (Dalmia and Lawrence 2005). ${ }^{7}$ In fact, the dowry facilitates negative assortative mating by providing a monetary mechanism with which the differences in measurable attributes between a couple are equalized. ${ }^{8}$

Gender inequality and biases, in terms of social and economic rights, are generally less pronounced in Southeast Asia compared to Sub-Saharan Africa and South Asia (Quisumbing, Otsuka and Estudillo 2004). In the Philippines, in particular, centuries of European influence, especially that of the Catholic Church, have resulted in the evolution of social institutions that promote pre-marital courtship and self-selection (rather than arranged marriages), greater independence of women, and more equal gender roles. About 70 percent of the married couples in our sample were not introduced by parents and other family members. As documented by

\footnotetext{
${ }^{5}$ There are some studies that support Becker's original prediction of negative assortative mating (e.g. Zimmer 1996).

${ }^{6}$ There are non-economic reasons for positive assortative mating, such as compatibility (of partners with similar intellectual capabilities and interests), evolutionary motives (desire of individuals to mate with partners with highly desirable traits), and selection effects (the greater exposure of individuals to potential partners with similar attributes). See, for example, Goldin 1992 and Torche 2010.

${ }^{7}$ Lewis and Oppenheimer (2000) observe the phenomenon of marrying down in educationally less advantaged areas of the U.S.

${ }^{8}$ Although there is some evidence of positive assortative mating in India, the strength of association is weaker than in the U.S., and the matching predicted better by age than by education (Dalmia and Lawrence 2001).
} 
Torche (2010) in a study of three Latin American countries with historical and cultural links to the Philippines, such institutions promote gender symmetry in assortative mating and educational homogamy even when female labor force participation is low (Torche 2010). In fact, our data indicate that there is educational homogamy in the Bicol villages. The simple correlation coefficient between years of schooling of spouses is $0.3973(\mathrm{n}=1135)$. As shown in Table 3, a majority of women at each education level (except for those with some college) have a spouse with the same educational attainment.

Table 3: Distribution of Husband's Education by Wife's Education Level

\begin{tabular}{|c|c|c|c|c|c|c|}
\hline & & \multicolumn{5}{|c|}{ Husband's Education } \\
\hline & & Elementary & Secondary & Some College & $\begin{array}{l}\text { College } \\
\text { Graduate }\end{array}$ & Obs \\
\hline \multirow{4}{*}{$\begin{array}{c}\text { Wife's } \\
\text { Education }\end{array}$} & Elementary & 55.62 & 35.11 & 4.33 & 3.96 & 809 \\
\hline & Secondary & 31.11 & 53.1 & 6.88 & 8.51 & 823 \\
\hline & Some College & 21.85 & 33.33 & 24.07 & 20.74 & 270 \\
\hline & College Graduate & 20.35 & 14.39 & 9.12 & 56.14 & 285 \\
\hline
\end{tabular}

A handful of empirical studies of developing countries_-Iran (Scully 1979), Brazil (Tiefenthaler 1997; Lam and Schoeni 1993), Taiwan (Zhang and Liu 2003), China (Huang et al. 2009) and the Philippines (Boulier and Rosenzweig 1984) — report a positive association of wife's schooling with husband's earnings. A similar pattern is reflected in our sample; according to Table 4, more than half of those with a college degree had a spouse with an income of 30,000 pesos or more, less than 30 percent of those with a secondary or vocational education, and just 17 percent of those with elementary education or no schooling. The spousal earnings distribution shifts to the right at all levels of wife's schooling except some college. The three pronounced shifts are relatively low spousal income (median 15,000-29,999) for women with at most an elementary education, moderate spousal income (median 30,000-59,999) for women with secondary education or some college, and high spousal income (median 60,000-99,999) for women with college degrees. The marriage rate, on the other hand, is not responsive to educational attainment. 
Table 4: Husband's Earnings by Wife's Education

\begin{tabular}{|c|c|c|c|c|c|c|c|c|c|}
\hline \multirow{2}{*}{$\begin{array}{c}\text { Wife's } \\
\text { education }\end{array}$} & \multicolumn{6}{|c|}{ Cumulative Frequency of Husband's Income } & \multirow{2}{*}{$\begin{array}{l}\text { Mean } \\
\text { Spousal } \\
\text { Income }\end{array}$} & \multirow{2}{*}{$\begin{array}{c}\text { Median } \\
\text { Spousal } \\
\text { Income } \\
\text { Range } \\
\end{array}$} & \multirow{2}{*}{$\begin{array}{c}\text { Marriage } \\
\text { rate }\end{array}$} \\
\hline & $\begin{array}{l}\text { Under } \\
6,000 \\
\end{array}$ & $\begin{array}{l}6,000- \\
14,999 \\
\end{array}$ & $\begin{array}{l}15,000- \\
29,999 \\
\end{array}$ & $\begin{array}{l}30,000- \\
59,999 \\
\end{array}$ & $\begin{array}{l}60,000- \\
99,999 \\
\end{array}$ & $\begin{array}{l}100,000- \\
199,000 \\
\end{array}$ & & & \\
\hline Elementary & 8.190 & 34.050 & 54.310 & 83.620 & 91.810 & 93.530 & 20099.660 & $\begin{array}{l}15,000- \\
29,999\end{array}$ & 0.578 \\
\hline Secondary & 6.110 & 18.770 & 34.930 & 72.920 & 87.330 & 93.010 & 27899.140 & $\begin{array}{l}30,000- \\
59,999\end{array}$ & 0.570 \\
\hline Some College & 13.110 & 27.860 & 40.970 & 57.360 & 85.230 & 93.430 & 27149.190 & $\begin{array}{l}30,000- \\
59,999\end{array}$ & 0.565 \\
\hline $\begin{array}{l}\text { College } \\
\text { Graduate }\end{array}$ & 1.520 & 7.580 & 16.670 & 48.490 & 74.250 & 89.400 & 48599.380 & $\begin{array}{l}60,000- \\
99,999 \\
\end{array}$ & 0.611 \\
\hline All & 7.140 & 24.490 & 41.160 & 72.790 & 87.420 & 92.860 & 26099.260 & $\begin{array}{l}30,000- \\
59,999\end{array}$ & 0.518 \\
\hline
\end{tabular}

The association between schooling and spousal earnings is typically attributed to assortative mating at marriage or cross-productivity effects between married couples. To support a schooling effect via assortative mating, a causal link between the wife's schooling and the husband's earnings at marriage must be established; if cross-productivity gains exist, the wife's education should have a causal effect on the post-marital gains in the husband's earnings, controlling for his own education. In the absence of data on earnings at marriage except in a handful of datasets (e.g. Huang et al. 2009), the separation of the two effects is difficult. Our goal is limited to estimating the combined causal effect. Identifying a causal effect in either case is complicated by the fact that schooling attainment and marriage choices may be jointly determined by a common set of unobservables. Boulier and Rosenzweig (1984) argue, for example, that women with exogenously negative marriage prospects are likely to acquire more schooling.

Finding instrumental variables to identify exogenous variation in women's schooling has been difficult because supply-side variables commonly used in studies of the impact of schooling (e.g. distance from school, variation in compulsory schooling laws, and school quality) are likely to affect not only the woman but also her potential husband (Card 1999; Lefgren and McIntyre 2006). To our knowledge, only two studies of either developed or developing countries have explicitly attempted to identify the causal effect from schooling to spousal earnings. Following Angrist and Krueger's (1991) study of returns to own schooling, 
Lefgren and McIntyre (2006) use the birth quarter to instrument for women's education in a regression of spousal earnings in the U.S. The authors take several steps to minimize the problems associated with weakness and excludability of the birth quarter instrument (Bound, Jaeger, and Baker 1995), but acknowledge the need for more relevant instruments. In any case, the birth quarter instrument is not applicable to countries such as the Philippines which does not have or enforce an age-based compulsory schooling that is binding. Huang et al. (2009) utilize a fixed effects estimator on a sample of monozygotic twins from China. Bound and Solon (1999) questioned the validity of this identifying assumption in previous research on returns to own schooling (e.g. Ashenfelter and Krueger 1994; Ashenfelter and Rouse 2000), arguing that there is substantial within-twins differences in unobservable attributes which may determine differences in spousal attributes. In Huang et al.'s (2009) sample of twins, the within-twin correlation of unobservables is suspected to be sufficiently large enough that the results are interpreted only as an upper bound for the estimated returns to spousal education.

In the next section, we propose an identification strategy which relies on variation in schooling due to the sibship structure in the family in which individuals were raised, and parental education. We argue that these instruments are relevant and valid in the context of the marriage market of the Philippines, and support this contention with formal specification tests for validity and relevance.

\section{REGRESSION MODEL AND IDENTIFICATION STRATEGY}

The regression models estimated relate schooling attainment of women with own earnings and spousal earnings. For comparison purposes, we also estimate men's own earnings as a function of their education. All three models correct for non-random sample selection and endogeneity of schooling by jointly estimating the following three equations with a maximum likelihood estimator. $^{9}$

$$
\begin{aligned}
& Y_{i}=\beta_{0}+\beta_{1} E_{i}+\beta_{2} X_{i}+\epsilon_{i} \text { if } D_{i}=1 \\
& \operatorname{Pr}\left(D_{i}=1\right)=\delta_{0}+\delta_{1} E_{i}+\delta_{2} X_{i}+\delta_{3} Z_{i}+\mu_{i} \\
& E_{i}=\gamma_{0}+\gamma_{1} X_{i}+\gamma_{2} Z_{i}+\vartheta_{i}
\end{aligned}
$$

\footnotetext{
${ }^{9}$ We use the cmp program for multi-equation conditional mixed models in Stata to carry out the estimation. See Roodman 2009 for details.
} 
where the subscript i refers to individual $\mathrm{i}, \mathrm{Y}$ is, in each of the three models, own earnings of females or own earnings of males and spousal earnings of females, $D$ is a dummy variable which indicates whether the dependent variables is observed, $\mathrm{E}$ is the educational attainment, $\mathrm{X}$ is a vector of other covariates, and $\mathrm{Z}$ is a vector of identifying exogenous variables which can be excluded from the equation (1). The error terms $\epsilon, \mu, \vartheta$ are assumed normally distributed and correlated with each other. Equation (1) is specified as an interval regression since the earnings variables are reported in intervals. Equation (2) is a probit equation which corrects for sample selectivity bias. In own earnings equations, the dummy variable D represents labor force participation, whereas in the spousal earnings equation, D represents the presence of a spouse who is in the labor market, i.e. the product of a dummy variable for marriage and a dummy variable for spouse's labor force participation. Equation (3) is linear and models the endogeneity of education. To examine the extent of bias due to sample selectivity and endogeneity, we compare the results of the three equation model with estimates of equation (1) and joint estimates of equations (1) and (2).

The definitions and descriptive statistics of all independent variables used are reported in Appendix 1. Since our subjects are married adult children, observed in 2003, of households originally surveyed in 1983, we have data on both the adult outcomes pertaining to the current nuclear family (e.g. own and spousal earnings) and childhood attributes pertaining to the original nuclear family, including a full roster of siblings and their characteristics. Our data satisfy the three requirements needed for a study of this type (Butcher and Case 1994; Hauser and Kuo 1998): 1) a sample of individuals with completed schooling; 2) information on the sibship structure of the family in which they were raised; and 3) a set of family and social background variables on the original family. The knowledge of the family structure provides a mechanism with which to instrument for completed schooling (Butcher and Case 1994). Specifically, the following instrumental variables $Z$ are used: 1 ) the size of sibship; 2) gender composition of sibship; 3) birth order; 4) father's schooling attainment; and 5) mother's schooling attainment. We use the sibship variables, but not parental education, to identify the sample selection equation.

The relevance of our instruments depends on the strength of their correlation with schooling attainment, and their validity depends on the excludability from the spousal earnings equation. Theoretically, the existence and direction of a birth order effect on schooling depends 
on the balance between the diminishing marginal utility in the allocation of parental time (which lead to a negative birth order effect) and parental learning-by-doing effects and increasing returns to scale in parenting (which lead to a positive birth order effect) (Behrman and Taubman 1986). The sibship size has a straightforward theoretical interpretation of resource constraints inhibiting schooling attainment of each child, and birth spacing has a similar interpretation of resource dilution related to competing demands of parental time and resources (Hauser and Kuo 1998). The effect of sibling sex composition is more complicated; if there are borrowing constraints and greater returns to the schooling of boys, an efficient household will invest less in the schooling of a daughter if there are sons present compared to when only sisters are present (Parish and Willis 1993; Butcher and Case 1994). If there are egalitarian preferences, the reverse is true because parents will compensate the lower marginal returns of girls with higher educational investments. If the cost of raising children of one gender is lower than that of the other (e.g. access to segregated schooling, contributions to family income), the schooling attainment of children of both genders increases when the proportion of siblings of the gender with low costs increases. In the traditional, patriarchal societies_particularly in Asia-parental preference for sons and seniority can also influence their allocation of educational resources (Parish and Willis 1993; Yu and Su 2006).

A large number of empirical studies have examined the effect of birth order, sibship size, and sibship sex composition on schooling, and find generally strong results even though there are differences in the direction and magnitude of the effects based on the cultural context and family structure of the study subjects. In societies with a preference for son, educational gender gaps have been observed at the household level but their magnitude reduces with household wealth (Yu and Su 2006; Rammohan and Dancer 2008). Behrman and Taubman (1986), Black, Devereux and Salvanes (2005) and Gary-Bobo, Picard, and Prieto (2006) find that early-born children (those with low rank) have better schooling outcomes. In Taiwan, Yu and Su (2006) find that the first-born son has an advantage but not the first-born daughter, suggesting a role played by parental preference for sons. In Egypt, on the other hand, later-born girls do better in school, whereas the first-born son is particularly disadvantaged (Rammohan and Dancer 2008). Although there is widespread consensus that sibship size is associated with negative schooling outcomes (Butcher and Case 1994; Hauser and Kuo 1998; Gary-Bobo, Picard, and Prieto 2006; $\mathrm{Yu}$ and Su 2006), the debate on the effects of sibship structure remains unresolved. Butcher and Case (1994) find sibship sex composition effects with women raised only with brothers 
receiving more education than those raised with at least one sister. Powell and Steelman (1989, 1990) find the opposite effect and Hauser and Kuo (1998) dispute both these findings. Using French data, Gary-Bobo, Picard, and Prieto (2006) find that the addition of a brother is more detrimental to the educational outcomes of girls than of boys and more detrimental to the educational outcomes of girls than the addition of a sister. Yu and Su (2006) find that being the minority gender, i.e. having more brothers than sisters, is helpful to female children in Taiwan.

As Lefgren and McIntyre (2006) point out, a valid instrument must vary across individuals, but not over time and place, and should not have independent effects on marriage outcomes. Clearly, the sibship structure is time-invariant and individual-specific. Although no other study, to our knowledge, has examined whether birth order and sibship structure affect marriage outcomes, there is evidence that birth order and sibship structure do not influence adult outcomes such as earnings, controlling for other childhood family background variables (Behrman and Taubman 1986, Butcher and Case 1994). In fact, Butcher and Case (1994) and Gary-Bobo, Picard, and Prieto (2006) use sibship size, sibling sex composition, and birth order as instruments in regressions of schooling and own earnings. The broader assumption is that birth order and sibship structure are orthorgonal to unobservables which jointly determine schooling, earnings, and marital outcomes.

Parental education, similarly, has been adopted as an instrument in the literature to estimate returns to education at the individual level (Trostel, Walker, and Woolley 2002; Ichino and Winter-Ebmer 1999; Lemke and Rischall 2003; Hoogerheide, Block, and Thurik 2010). However, the exclusion restriction that parental education has no direct effect on earnings has been considered by some as problematic. Card (1999) argues, for example, that family background is likely to provide upwardly biased estimates of the average return to schooling not only because family background has an independent causal effect on earnings, but also because ability is likely to persist across generations. But, as Trostel, Walker, and Woolley (2002) point out, validity is ultimately an empirical question. In fact, using a multitude of established techniques, they show that parental education is a valid instrument for educational outcomes in several countries. Lemke and Rischall (2003) and Hoogerheide, Block, and Thurik (2010) also downplay the across-the-board criticism of family background variables such as parental education as unjustified. They contend that the size of the bias in IV models based on family background instruments is generally smaller than in IV models based on supply-side and institutional frameworks. Although the debate on the excludability of parental education from 
wage equation cannot be resolved for good, we rely on three arguments to justify their validity in our specific context: 1) Unlike much of the studies which have participated in this debate, our primary focus is returns through marriage market; thus, spouse's wage equation and not the individual wage equation, is our primary concern. The case for excluding parental education from spousal earnings is stronger than the case for excluding it from own education. 2) We also include sibship information—birth order, gender composition, and size in the set of instruments-whose validity as instruments is theoretically less contentious. 3) Appropriate tests of excludability and strength can be run to resolve these concerns more definitively. Once the theoretical validity of at least some of the sibship variables is established, we rely on overidentification tests to confirm the excludability of parental education.

\section{REGRESSION RESULTS}

Table 5 reports the education coefficient obtained for 1) log own earnings for women, 2) $\log$ spousal earnings for women, and 3) log own earnings for men in three specifications: The first specification estimates equation (1) using an interval regression. The second specification corrects for sample selection bias by jointly estimating equations (1) and (2). The third specification estimates equations (1), (2), and (3), jointly correcting for both sample selectivity and endogeneity bias.

The benchmark single equation specification estimates own returns to education at 11.52 percent for women and 5.72 percent for men. This result conforms with the finding in previous studies that Filipino women experience considerably higher labor market returns to education than their male counterparts. In addition, women are estimated to reap a 6.445 percent return to a year of schooling through marriage. Women who choose to stay out of the labor market appear to benefit from schooling more than men who participate in the labor market. When we correct for sample selectivity bias using birth order, sibship size, and proportion of male siblings as identifying variables, the returns estimates do not change significantly; own returns estimates are marginally larger and spousal returns estimates are marginally smaller. The lack of sensitivity of estimates of schooling returns to sample selectivity corrections has been observed widely in the literature (e.g. Dearden 1998). 
Table 5: Returns to Schooling Estimates

\begin{tabular}{|l|l|l|}
\hline \multirow{4}{*}{ Dependent Variable } & \multicolumn{1}{|c|}{ Model Specification } & $\begin{array}{l}\text { Education } \\
\text { Coeff (S.E) }\end{array}$ \\
\hline \multirow{3}{*}{ Own Income for Females } & $(1)-$ Equation (1) & $0.115(.014)$ \\
\cline { 2 - 3 } & (2)-Equation (1) and (2) & $0.102(.027)$ \\
\cline { 2 - 3 } & $\mathbf{( 3 )}-$ Equation (1), (2) and (3) & $\mathbf{0 . 2 0 6}(.030)$ \\
\hline \multirow{3}{*}{ Spousal Income for Females } & $(1)-$ Equation (1) & $0.064(.014)$ \\
\cline { 2 - 3 } & $(2)-$ Equation (1) and (2) & $0.062(.015)$ \\
\cline { 2 - 3 } & $\mathbf{( 3 )}-$ Equation (1), (2) and (3) & $\mathbf{0 . 1 9 4}(\mathbf{. 0 3 8})$ \\
\hline \multirow{3}{*}{ Own Income for Males } & $(1)-$ Equation (1) & $0.057(.009)$ \\
\cline { 2 - 3 } & $(2)-$ Equation (1) and (2) & $0.067(.012)$ \\
\cline { 2 - 3 } & $\mathbf{( 3 )}-$ Equation (1), (2) and (3) & $\mathbf{0 . 1 2 1}(\mathbf{. 0 2 3})$ \\
\hline
\end{tabular}

We then estimate a three equation model which uses birth order, sibship size, proportion of male siblings, and parental education to instrument for years of schooling. The IV estimates are substantially larger than those obtained in the first two models; the return for a year of schooling in terms of own earnings is 20.6 percent for women and 12.1 percent for men. The return in terms of spousal earnings of women is 19.4 percent. All coefficients are highly significant at less than 1 percent level. The IV estimates suggest that the failure to account for the endogeneity leads to estimates which are heavily biased downwards. The results reveal that Filipino women experience gains from schooling which are about seven to eight percentage points larger than the labor market returns to men-whether or not they participate in the labor market. Substantial marriage market returns which are remarkably similar in magnitude to labor market returns allow women to separate the schooling decision from the labor force participation decision.

Table 6 reports the complete results of the three equation model. Estimates of equation (1) show that, in addition to the schooling effects already discussed, own earnings increase with age at an increasing rate for women and at a diminishing rate for men, and is not influenced by household wealth and family background as measured by the extent of land owned in 1983 by the family in which they grew up. Spousal earnings of women are significantly predicted by schooling but not by age or land ownership. The latter result supports our contention that Filipino women achieve assortative mating in marriage through schooling rather than through family background. The inclusion of initial land ownership as a control for family background also helps us to build a case for the exclusion of parental education in the earnings equations. 
Equation (2) corrects for selectivity. In the own earnings models, the dependent variable is a dummy variable which signifies the labor force participation status. The estimates show that the likelihood of employment increases with age (non-linearly) and decreases with birth order for both men and women. There are also weak negative effects due to sibship size for both genders due to gender composition of siblings for women. For men, there is a negative association between schooling and labor force participation, whereas there is no significant effect for women. In the spousal earnings model, the dependent variable is a dummy variable which denotes whether the individual has a spouse who is employed. The likelihood of being married and having an employed spouse is positively related with age and negatively related with birth order, number of siblings, and schooling. 
Table 6: Complete Results of the Three Equation Model

\begin{tabular}{|c|c|c|c|c|c|c|c|c|c|}
\hline & \multicolumn{3}{|c|}{ Own Earnings - Females } & \multicolumn{3}{|c|}{ Spousal Earnings - Females } & \multicolumn{3}{|c|}{ Own Earnings - Males } \\
\hline VARIABLE & $\begin{array}{c}\log \text { Own } \\
\text { Earnings } \\
\text { Interval }\end{array}$ & Selectivity & Education & $\begin{array}{c}\text { log } \\
\text { Spouse's } \\
\text { Earnings } \\
\text { Interval }\end{array}$ & Selectivity & Education & $\begin{array}{c}\log \text { Own } \\
\text { Earnings } \\
\text { Interval }\end{array}$ & Selectivity & Education \\
\hline \multirow[t]{2}{*}{ Education } & $0.206 * * *$ & -0.003 & & $0.194 * * *$ & $-0.111 * * *$ & & $0.121 * * *$ & $-0.046 * * *$ & \\
\hline & 0.03 & 0.019 & & 0.039 & 0.015 & & 0.023 & 0.017 & \\
\hline \multirow[t]{2}{*}{ Age } & -0.054 & $0.098 * * *$ & $0.570 * * *$ & -0.047 & $0.172 * * *$ & $0.569 * * *$ & $0.074 * *$ & $0.156 * * *$ & $0.545^{* * *}$ \\
\hline & 0.034 & 0.012 & 0.019 & 0.060 & 0.011 & 0.019 & 0.034 & 0.009 & 0.018 \\
\hline \multirow[t]{2}{*}{ Age squared } & $0.001^{* *}$ & $-0.001 * * *$ & $-0.007 * * *$ & 0.0007 & $-0.002 * * *$ & $-0.007 * * *$ & $-0.001^{* *}$ & $-0.002 * * *$ & $-0.006 * * *$ \\
\hline & 0.0004 & 0.0002 & 0.0002 & 0.0007 & 0.0001 & 0.0003 & 0.0004 & 0.0001 & 0.0002 \\
\hline \multirow[t]{2}{*}{$\begin{array}{l}\text { Father's } \\
\text { education }\end{array}$} & & & $0.187 * * *$ & & & $0.208^{* * *}$ & & & $0.190 * * *$ \\
\hline & & & 0.029 & & & 0.028 & & & 0.026 \\
\hline \multirow[t]{2}{*}{$\begin{array}{l}\text { Mother's } \\
\text { education }\end{array}$} & & & $0.262 * * *$ & & & $0.244^{* * *}$ & & & $0.223^{* * *}$ \\
\hline & & & 0.030 & & & 0.029 & & & 0.027 \\
\hline \multirow[t]{2}{*}{ Birth order } & & $-0.218 * *$ & $0.664 * * *$ & & $-0.188 * *$ & $0.619 * *$ & & $-0.195 * * *$ & $0.624 * * *$ \\
\hline & & 0.089 & 0.248 & & 0.084 & 0.244 & & 0.075 & 0.23 \\
\hline \multirow[t]{2}{*}{$\begin{array}{l}\text { Male sibling } \\
\text { pct }\end{array}$} & & $-0.255^{*}$ & $-0.970 * * *$ & & 0.055 & $-1.107 * * *$ & & -0.007 & -0.384 \\
\hline & & 0.134 & 0.365 & & 0.134 & 0.359 & & 0.118 & 0.338 \\
\hline \multirow[t]{2}{*}{$\begin{array}{l}\text { Number of } \\
\text { siblings }\end{array}$} & & $-0.019 *$ & $-0.209 * * *$ & & $-0.029 * * *$ & $-0.206 * * *$ & & $-0.017 *$ & $-0.173 * * *$ \\
\hline & & 0.011 & 0.027 & & 0.010 & 0.027 & & 0.009 & 0.026 \\
\hline \multirow[t]{2}{*}{$\begin{array}{l}\text { Family- } \\
\text { Owned Land }\end{array}$} & -0.003 & 0.011 & $0.092 * * *$ & 0.010 & 0.013 & $0.091 * * *$ & -0.010 & -0.006 & $0.119 * * *$ \\
\hline & 0.014 & 0.009 & 0.031 & 0.014 & 0.009 & 0.030 & 0.012 & 0.009 & 0.031 \\
\hline \multirow[t]{2}{*}{ Constant } & $8.795 * * *$ & $-2.139 * * *$ & $-2.088 * * *$ & $9.337 * * *$ & $-2.411 * * *$ & $-2.000 * * *$ & $7.423 * * *$ & $-2.399 * * *$ & $-2.764 * * *$ \\
\hline & 1.012 & 0.229 & 0.53 & 1.344 & 0.266 & 0.523 & 0.733 & 0.202 & 0.483 \\
\hline Observations & 2,909 & 2,909 & 2,909 & 2,907 & 2,907 & 2,907 & 3,164 & 3,164 & 3,164 \\
\hline & & & & & & & & & \\
\hline
\end{tabular}

${ }^{* * *} \mathrm{p}<0.001,{ }^{* *} \mathrm{p}<0.05,{ }^{*} \mathrm{p}<0.1$

Women's education, according to equation (3), is strongly influenced by the instrumental variables. Parental education has a highly significant (at 1 percent level) and large (between 0.187 and 0.26 years) impact on the schooling attainment of children. As documented in the literature (e.g. Thomas 1994), mother's schooling has an impact on children's outcomes which is larger (between 0.03 to 0.08 years in our case) than that of father's schooling. Birth order (i.e. being a younger sibling) has a positive and significant (at 5 percent or less) impact on 
educational attainment for both men and women; a change in birth order from oldest (0) to youngest (1) results in a 0.06 to 0.07 increase in years of schooling. This is consistent with learning-by-doing and scale economies effects which dominate diminishing marginal utility effects. In the Filipino context, it is also possible that younger children are provided with more schooling to compensate for the larger land and asset transfer which are traditionally given to the older children (Estudillo, Quisumbing and Otsuka 2001a). As predicted by the quantityquality trade-off in the presence of resource constraints, a unit increase in sibship size has a negative and highly significant (at 1 percent) effect of about 0.21 years for females and 0.17 years for males. Sibling gender composition has a statistically significant effect only for females; if a female has siblings who are all male rather than all female, she is estimated to have approximately one less year of schooling. An efficient household may provide more schooling to sons if returns to schooling are higher for males. However, since we obtain relatively higher returns to schooling for females, this result appears more in line with the presence of some gender bias in favor of boys in the parental allocation of resources (Powell and Steelman 1989, Powell and Steelman 1990, Gary-Bobo, Picard, and Prieto 2006).

\section{TESTS FOR VALIDITY AND RELEVANCE OF INSTRUMENTS}

Since it is nearly impossible to find variables that are both relevant and unambiguously valid in non-experimental studies of returns to schooling (Trostel, Walker, and Woolley 2002), we rely on empirical evidence to build our case for identification. Unfortunately, over-identification and relevance tests have not been developed for the maximum likelihood model which accounts for the non-linearity of the dependent variable and sample selectivity bias. Consequently, all formal tests presented in this section are based on a linear two-stage least squares regression which used the midpoint of the income intervals as a point estimate for actual income. As shown in Appendix 2, the results are qualitatively very similar to those obtained from the maximum likelihood estimates, and are reported in Table 6.

The specification tests reported in Table 7 show that our instrumental variables are clearly relevant. The partial $\mathrm{R}$ squares in the first stage regressions provides evidence that the instrumental variables explain a substantial portion of the variation in schooling for both men and women (Bound, Jaeger, and Baker 1995). Moreover, F-statistics for the joint significance of 
the instruments comfortably exceed the rule of thumb level of 10 (Staiger and Stock 1997) and further corroborate the relevance of the instruments.

Table 7: Summary of Specification Tests

\begin{tabular}{|l|l|c|c|c|}
\hline \multicolumn{2}{|c|}{ Tests } & $\begin{array}{l}\text { Female Own } \\
\text { Income }\end{array}$ & $\begin{array}{l}\text { Female Spousal } \\
\text { Income }\end{array}$ & $\begin{array}{l}\text { Male Own } \\
\text { Income }\end{array}$ \\
\hline $\begin{array}{l}\text { Strength } \\
\text { /Relevance }\end{array}$ & Joint F- test & 33.6136 & 22.6786 & 57.2131 \\
\cline { 2 - 5 } & Partial R sq & 0.2302 & 0.1768 & 0.2212 \\
\hline \multirow{2}{*}{$\begin{array}{l}\text { Validity } \\
\text { /Over-identification }\end{array}$} & Sargan Chi Square & $\begin{array}{c}1.6989 \\
(\mathrm{p}=0.7909)\end{array}$ & $\begin{array}{c}3.64564 \\
(\mathrm{p}=0.4561)\end{array}$ & $\begin{array}{c}6.02658 \\
(\mathrm{p}=0.1972)\end{array}$ \\
\cline { 2 - 5 } & Basmann Chi sq & $\begin{array}{c}1.67711 \\
(\mathrm{p}=0.7949)\end{array}$ & $\begin{array}{c}3.60904 \\
(\mathrm{p}=0.4615)\end{array}$ & $\begin{array}{c}6.00884 \\
(\mathrm{p}=0.1985)\end{array}$ \\
\hline $\begin{array}{l}\text { Endogeneity of } \\
\text { education }\end{array}$ & Hausman Chi sq & $\begin{array}{c}9.17 \\
(\mathrm{p}=0.0569)\end{array}$ & $\begin{array}{c}8.51 \\
(\mathrm{p}=0.0747)\end{array}$ & $\begin{array}{c}20.26 \\
(\mathrm{p}=0.0004)\end{array}$ \\
\hline
\end{tabular}

The validity of our IV estimates depends on the exclusion restriction that sibship characteristics and parental education does not affect own and spousal earnings, controlling for own education and land ownership. Theoretically, we rely on the fact that, for historical and cultural reasons, families play a relatively minor role in the choice of marriage partners - unlike in many other Asian and African cultures. In our data, a majority of married individuals met their future spouses at school or at work, and only about 30 percent of all females were introduced to their spouses by their parents or other family members. The assumption of excludability is corroborated by the jointly and individually insignificant coefficients we obtained when the instrumental variables are included in Equation (1) as additional regressors (results not reported). Sargan's (1958) and Basmann's (1960) tests of over-identifying restrictions show that the hypothesis of excludability of instruments cannot be rejected ( $\mathrm{p}>0.1)$. Since over-identification tests can establish exogeneity only if at least one instrument is assumed excludable, we rely on the assumption that at least some of our instruments-birth order and sibling gender composition —are exogenous to test for over-identification of the theoretically more contentious instruments—-sibship size and parental education.

Once the relevance and validity of the instruments is established, endogeneity of the education variable is tested using the Durbin-Wu-Hausman test. The hypothesis of exogeneity of the education is rejected at between 5 and 10 percent significance for females, and at less than 1 percent significance for males. These results generally show that OLS coefficients are not consistent and that instrumenting for education is necessary. 


\section{CONCLUSIONS}

As proclaimed in the third Millennium Development Goal, eliminating gender disparities in education is among the top priorities for developing countries. The Philippines stands out in this regard as a rare success story and an example which can be emulated. However, the reasons for the absence of a gender schooling gap are not well understood. Estudillo, Quisumbing, and Otsuka (2001b) find limited evidence of egalitarian gender-specific inter-generational transfer patterns in which land inheritance to sons is compensated with schooling investments for daughters. Several studies have documented high labor market returns to schooling for women (Lanzona 1998; Trostel, Walker, and Woolley 2002; Sakellariou 2004). Using IV regressions which also correct for sample selection bias, we find that labor market returns are approximately 20 percent for women and 12 percent for men. These estimates are remarkably similar to those reported for the Philippines by Trostel, Walker, and Woolley (2002) and the returns to women are noticeably higher than the averages reported in surveys of empirical studies worldwide (Psacharopolous 1994; Trostel, Walker, and Woolley 2002; Psacharopolous and Patrinos 2004).

However, labor market returns that favor women would not necessarily cause the gender schooling gap to disappear if average wages are low and a large proportion of women consequently remain outside the labor market. The presence of a low labor force participation for women-56 percent compared to 86 percent for men —in the Bicol, despite parity in educational attainment, motivated us to examine whether there are household-level pecuniary returns to women's education through a causal relationship between schooling and spousal earnings. Our results show that this is, indeed, the case with women experiencing returns in the marriage market that are as large as the returns in the labor market. There is a large amount of literature which demonstrates theoretically and empirically how the causal effect of education on spousal earnings arises from assortative mating in marriage and cross-productivity effects in the household. In the Philippine marriage market, unlike in many other Asian and African countries, individuals have substantial freedom to choose their own spouses, and educational homogamy is widely observed. It appears that the practice of educational homogamy has facilitated the attainment of gender parity in schooling by encouraging parents to invest in the schooling of girls regardless of whether or not they expect their daughters to eventually enter the labor force. 
From a policy perspective, the analysis presented in this paper presents a cautionary tale for developing countries who rely on supply-side interventions and on the provision of skilled employment prospects for women to narrow the gender schooling gap. So long as traditional marriage practices such as arranged marriages and dowry exist, and if intra-household specialization of the sort predicted by the exchange model (Becker 1974) continues to encourage educational heterogamy, investment in the schooling of girls may remain low. If multiple equilibria arise from non-convexities in the household level schooling-earnings function when the labor force participation decision is incorporated, educational inequality can emerge for females - with the few who are able to obtain highly skilled occupations acquiring high levels of educations, and the rest leaving school, staying out of the labor market and specializing in home production. Reducing the average gender earnings gap, in addition to reducing the gender gap in returns to schooling, can help alleviate this situation by encouraging relatively low-skilled women to enter the labor force. 


\section{REFERENCES}

Alderman, Harold and Elizabeth M. King. 1998. "Gender Differences in Parental Investment in Education. Structural Change and Economic Dynamics 9(4):453-468.

Angrist, Joshua D. and Alan B. Krueger. 1991. "Does Compulsory School Attendance Affect Schooling and Earnings?” Quarterly Journal Of Economics 106(4):979-1014.

Ashenfelter, Orley and Alan B. Krueger. 1994. "Estimates of the Economic Returns to Schooling From a New Sample of Twins.” American Economic Review 84(5):11571173.

Ashenfelter, Orley and Rouse, Cecilia. 2000. Schooling, Intelligence, and Income in America: Cracks in the Bell Curve.” In K. Arrow, S. Durlauf and S. Bowles (eds.) Meritocracy and Inequality. Princeton, NJ: Princeton University Press.

Basmann, R.L. 1960. "On Finite Sample Distributions of Generalized Classical Linear Identifiability Test Statistics.” Journal of the American Statisical Association 55(292):650-59.

Becker, Gary S. 1973. “A Theory of Marriage: Part I.” Journal of Political Economy 81(4):813846.

Becker, Gary S. 1974. “A Theory of Social Interactions.” Journal of Political Economy 82(6):1063-93.

Becker, Gary S. 1981. "Altruism in the Family and Selfishness in the Market Place.” Economica 48(189):1-15.

Benham, Lee. 1974. “Benefits of Women’s Education within Marriage.” Journal of Political Economy 82(2):57-71.

Behrman, Jere R. and Anil B. Deolalikar. 1995. "Are There Differential Returns to Schooling by Gender? The Case of Indonesian Labour Markets.” Oxford Bulletin of Economics and Statistics 57(1):97-117.

Behrman, Jere R., and Taubman, Paul. 1986. "Birth Order, Schooling, and Earnings.” Journal Of Labor Economics 4(3):S121-45.

Black, Sandra E., Paul G. Devereux, and Kjell G. Salvanes. 2005. "The More the Merrier? The Effect of Family Size and Birth Order on Children's Education.” Quarterly Journal of Economics 120(2):669-700. 
Bicol River Basin Development Program. 1983. Bicol Multipurpose Survey (BMS):

[Philippines] [Computer file]. ICPSR06889-v1. Ann Arbor, MI: Inter-university Consortium for Political and Social Research [distributor], 1998. doi:10.3886/ICPSR06889.v1.

Boulier, Brian L. and Mark R. Rosenzweig. 1984. "Schooling, Search, and Spouse Selection: Testing Economic Theories of Marriage and Household Behavior.” Journal of Political Economy 92(4):712-32.

Bound, John, David A. Jaeger, and Regina M. Baker. 1995. "Problems with Instrumental Variables Estimation When the Correlation between the Instruments and the Endogenous Explanatory Variables is Weak." Journal of the American Statistical Association 90(430):443-50.

Bound, John and Gary Solon. 1999. "Double Trouble: On the Value of Twins-Based Estimation of the Return to Schooling.” Economics Of Education Review 18(2):169-182.

Brien, Michael J. 1997. "Racial Differences in Marriage and the Role of Marriage Markets." Journal of Human Resources 32(4):741-78.

Butcher, Kristin F. and Anne Case. 1994. "The Effect of Sibling Sex Composition on Women's Education and Earnings.” Quarterly Journal Of Economics 109(3):531-563.

Card, David. 1999. “The Causal Effect of Education on Earnings.” In O. Ashenfelter \& D. Card (eds.) Handbook of Labor Economics Volume 3. Amsterdam: Elsevier.

Dalmia, Sonia and Pareena G. Lawrence. 2001. “An Empirical Analysis of Assortative Mating in India and the U.S” International Advances in Economic Research 7(4):443-458.

Dalmia, Sonia and Pareena G. Lawrence. 2005. “The Institution of Dowry in India: Why It Continues to Prevail.” The Journal of Developing Areas 38(2):71-93.

Dearden, Lorraine. 1998. “Ability, families, education and earnings in Britain.” IFS Working Papers W98/14. London, UK: Institute for Fiscal Studies.

Deolalikar, Anil B. (1993). "Gender Differences in the Returns to Schooling and in School Enrollment Rates in Indonesia.” Journal of Human Resources 28(4):899-932.

DeSilva, Sanjaya. 2011. "Access to markets and farm efficiency: Evidence from rice farms in the Bicol region, Philippines.” Working Paper No. 687. Annandale-On-Hudson, NY: Levy Economics Institute of Bard College. 
Estudillo, Jonna.P., Agnes R. Quisumbing, and Keijiro Otsuka. 2001a. "Gender Differences in Wealth Transfer and Expenditure Allocation: Evidence from the Rural Philippines.” Developing Economies 39(4):366-394.

Estudillo, Jonna.P., Agnes R. Quisumbing, and Keijiro Otsuka. 2001b. "Gender Differences in Land Inheritance and Schooling Investments in the Rural Philippines.” Land Economics 77(1):130-143.

Gary-Bobo, Robert J., Natalie Picard, and Ana Prieto. 2006. "Birth Order and Sibship Sex Composition as Instruments in the Study of Education and Earnings.” CEPR Discussion Paper No.5514. London, UK: Center for Economic Policy Research.

Glick, Peter and David E. Sahn. 1997. "Gender and Education Impacts on Employment and Earnings in West Africa: Evidence from Guinea.” Economic Development and Cultural Change 45(4):793-823.

Goldin, Claudia. 1992. The Meaning of College in the Lives of American Women: The Past One-Hundred Years. Unpublished manuscript. Cambridge: Harvard University.

Grossbard-Shechtman, Amyra and Neuman, Shoshana. 1991. "Cross-Productivity Effects of Education and Origin on Earnings: Do They Really Reflect Productivity?” In J. Gerber, R. Frantz and H. Singh (eds.) Handbook of Behavioral Economics, Vol. II. Greenwich: JAI Press.

Groothuis, Peter and Paul E. Gabriel. 2010. "Positive Assortative Mating and Spouses as Complementary Factors of Production: A Theory of Labor Augmentation.” Applied Economics 42:1101-1111.

Hauser, Robert M. and Hsiang-Hui Daphne Kuo. 1998. "Does the Gender Composition of Sibships Affect Women's Educational Attainment?” Journal of Human Resources: 33(3):644-657.

Haveman, Robert H. and Barbara L. Wolfe. 1984. "Schooling and Economic Well-Being: The Role of Nonmarket Effects.” Journal of Human Resources 19(3):377-407.

Hill, M. Anne and Elizabeth M. King. 1995. "Women's Education and Economic Well-Being.” Feminist Economics 1(2):21-46.

Hoogerheide1, Lennart, Joern H. Block, and Roy Thurik. 2010. "Family Background Variables as Instruments for Education in Income Regressions: A Bayesian Analysis.” Tinbergen Institute Discussion Papers 10-075/3. Amsterdam and Rotterdam: Tinbergen Institute. 
Huang, Chong, Hongbin Li, Pak Wai Liu, and Junsen Zhang. 2009. "Why Does Spousal Education Matter for Earnings? Assortative Mating or Cross-productivity.” Journal of Labor Economics 27:633-652.

Ichino, Andrea and Rudolf Winter-Ebmer. 1999. "Lower and Upper Bounds of Returns to Schooling: An Exercise in IV Estimation with Different Instruments.” European Economic Review 43(4-6):889-901.

Jepsen, Lisa. 2005. “The Relationship Between Wife's Education and Husband's Earnings: Evidence from 1960 to 2000.” Review of Economics of The Household 3(2):197-214.

Jolliffe, Dean. 2002. "Whose Education Matters in the Determination of Household Income? Evidence from a Developing Country.” Economic Development and Cultural Change 50(2):287-312.

Kenny, Lawrence W. 1983. “The Accumulation of Human Capital during Marriage by Males.” Economic Inquiry 21:223-31.

King, Elizabeth M. 1996. “Education, Work and Earnings of Peruvian Women.” Economics of Education Review 15(3):213-230.

King, Elizabeth M. and M. Anne Hill, eds. 1993. Women's Education in Developing Countries: Barriers, Benefits and Policies. Baltimore: Johns Hopkins University Press.

King, Elizabeth M. and Lee A. Lillard. 1987. "Education Policy and Schooling Attainment in Malaysia and the Philippines.” Economics of Education Review 6:167-181.

Lam, David. 1988. "Marriage Markets and Assortative Mating with Household Public Goods: Theoretical Results and Empirical Implications.” Journal of Human Resources 23(4):462-487.

Lam, David and Robert F. Schoeni. 1993. "Effects of Family Background on Earnings and Returns to Schooling: Evidence from Brazil.” Journal Of Political Economy 101(4):710740.

Lanzona, Leonard. 1994. Bicol Multipurpose Survey (BMS): [Philippines] [Computer file]. ICPSR06890-v1. New Haven, CT: Yale University [producer], 1994. Ann Arbor, MI: Inter-university Consortium for Political and Social Research [distributor], 1997. doi:10.3886/ICPSR06890.v1.

Lanzona, Leonard. 1998. “Migration, Self-selection and Earnings in the Philippines.” Journal of Development Economics 56(1):27-50. 
Lefgren, Lars and Frank McIntyre. 2006. “The Relationship between Women's Education and Marriage Outcomes.” Journal of Labor Economics 24(4):787-830.

Lemke, Robert and Isaac C. Rischall. 2003. "Skill, Parental Income, and IV Eestimation of the Returns to Schooling.” Applied Economics Letters 10(5):281-286,

Lewis, Susan K. and Valerie K. Oppenheimer. 2000. "Educational Assortative Mating across Marriage Markets: Non-Hispanic Whites in the United States.” Demography 37(1):2940.

Liu, Pak-Wai and Junsen Zhang. 1999. “Assortative Mating Versus the Crossproductivity Effect.” Applied Economics Letters 6:523-25.

Loh, Eng Seng. 1996. "Productivity Differences and the Marriage Wage Premium for White Males.” Journal of Human Resources 31:566-89.

Mare, Robert. 1991. "Five Decades of Educational Assortative Mating.” American Sociological Review 56:15-32.

Olsen, Randall J. 2008. “The Desirability of Partner Traits and Two Decades of Change in the Marriage Market: A One-and-a-Half Sex Model of Marriage” Unpublished manuscript. Columbus, OH: Ohio State University Department of Economics.

Parish, William L. and Robert J. Willis. 1993. "Daughters, Education, and Family Budgets Taiwan Experiences.” Journal of Human Resources 28(4):863-898.

Pencavel, John. 1998. “Assortative Mating by Schooling and the Work Behavior of Wives and Husbands.” American Economic Review 88(2):326-29.

Powell, Brian and Lala Carr Steelman. 1989. "The Liability of Having Brothers: Paying for College and the Sex Composition of the Family.” Sociology of Education 62:134-147.

Powell, Brian and Lala Carr Steelman. 1990. “Beyond Sibship Size: Sibling Density, Sex Composition, and Educational Outcomes.” Social Forces 69:181-206.

Psacharopoulos, George. 1994. "Returns to Investment in Education: A Global Update.” World Development 22(9):1325-1343.

Psacharopoulos, George and Harry Anthony Patrinos. 2004. "Returns to Investment in Education: A Further Update.” Education Economics 12(2):111-134. 
Rammohan, Anu and Diane Dancer. 2008. "Gender Differences in Intrahousehold Schooling Outcomes: The Role of Sibling Characteristics and Birth-Order Effects.” Education Economics 16(2):111-126.

Qian, Zhenchao. 1998. "Changes in Assortative Mating: The Impact of Age and Education, 1970-1990.” Demography 35(3):279-92.

Quisumbing, Agnes R., Jonna P. Estudillo, and Keijiro Otsuka. 2004. Land and Schooling: Transferring Wealth across Generations. Baltimore and London: Johns Hopkins University Press.

Roodman, David. 2009. "Estimating Fully Observed Recursive Mixed Processes with cmp.” Working Paper No, 168. Washington, D.C.: Center for Global Development.

Sakellariou, Chris. 2004. "The Use of Quantile Regressions in Estimating Gender Wage Differentials: A Case Study of the Philippines.” Applied Economics 36:1001-1007.

Sargan, J.D. 1958. “The Estimation of Economic Relationships using Instrumental Variables.” Econometrica 26:393-415.

Scully, Gerald W. 1979. "Mullahs, Muslims, and Marital Sorting.” Journal of Political Economy 87 (5):1139-43.

Staiger, Douglas and James H. Stock. 1997. "Instrumental Variables Regression with Weak Instruments.” Econometrica 65(3):557-586.

Tiefenthaler, Jill. 1997. "The Productivity Gains of Marriage: Effects of Spousal Education on Own Productivity across Market Sectors in Brazil.” Economic Development and Cultural Change 45(3):633-650.

Thomas, Duncan. 1994. "Like Father, like Son; Like Mother, like Daughter: Parental Resources and Child Height." Journal of Human Resources 29(4):950-988.

Torche, Florencia. 2010. "Educational Assortative Mating and Economic Inequality: A Comparative Analysis of Three Latin American Countries.” Demography 47(2):481502.

Trostel, Philip, Ian Walker, and Paul Woolley. 2002. "Estimates of the Economic Return to Schooling for 28 Countries.” Labour Economics 9(1):1-16. 
United Nations. 2010. “Goal 3: Promote gender equality and empower women.” Fact Sheet. New York: Department of Public Information.

http://www.un.org/millenniumgoals/pdf/MDG_FS_3_EN.pdf

Welch, Finis. 1974. "Benefits of Women's Education within Marriage: Comment.” Journal of Political Economy 82(2):72-75.

Wong, Yue-Chim. 1986. "Entrepreneurship, Marriage, and Earnings.” Review of Economics and Statistics 68(4):693-99.

Yu, Wei-hsin and Kuo-hsien Su. 2006. "Gender, Sibship Structure, and Educational Inequality in Taiwan: Son Preference Revisited.” Journal of Marriage and Family 68:1057-1068.

Zhang, Junsen and Pak-Wai Liu. 2003. "Testing Becker's Prediction on Assortative Mating on Spouses' Wages.” Journal of Human Resources 38 (1):99-110.

Zimmer, Michael. 1996. "Assortative Mating and Ethnicity in the Low Wage Population: An Examination of Spouses’ Earning.” Applied Economics Letters 3:311-315. 
APPENDIX 1: INDEPENDENT VARIABLE DESCRIPTIONS AND DESCRIPTIVE STATISTICS

\begin{tabular}{|l|c|c|c|c|}
\hline & \multicolumn{2}{|c|}{ Females } & \multicolumn{2}{c|}{ Males } \\
\hline Variable & Mean & Std. Dev. & Mean & Std. Dev. \\
\hline Education (years) & 9.126 & 4.881 & 8.491 & 4.706 \\
\hline Mother's education (years) & 7.452 & 3.490 & 7.374 & 3.522 \\
\hline Father's education (years) & 7.533 & 3.369 & 7.454 & 3.443 \\
\hline Age & 31.037 & 14.965 & 31.398 & 15.027 \\
\hline $\begin{array}{l}\text { Parental land owned } \\
\text { (hectares) }\end{array}$ & 0.682 & 2.607 & 0.704 & 2.434 \\
\hline Birth order (scaled 0-1) & 0.497 & 0.334 & 0.488 & 0.335 \\
\hline Number of siblings & 7.268 & 3.038 & 7.356 & 3.042 \\
\hline Male siblings (percent) & 0.522 & 0.207 & 0.503 & 0.210 \\
\hline
\end{tabular}




\section{APPENDIX 2: LINEAR IV REGRESSION RESULTS USED FOR SPECIFICATION TESTS}

\begin{tabular}{|c|c|c|c|c|c|c|c|c|c|}
\hline & \multicolumn{3}{|c|}{ Own Income - Females } & \multicolumn{3}{|c|}{ Spousal Income - Females } & \multicolumn{3}{|c|}{ Own Income - Males } \\
\hline & \multirow{2}{*}{$\begin{array}{c}\text { OLS } \\
\text { Log } \\
\text { Own- } \\
\text { Income }\end{array}$} & \multicolumn{2}{|c|}{ Linear 2SLS } & \multirow{2}{*}{$\begin{array}{c}\text { OLS } \\
\text { Log } \\
\text { Spousal } \\
\text { Income }\end{array}$} & \multicolumn{2}{|c|}{ Linear 2SLS } & \multirow{2}{*}{$\begin{array}{c}\text { OLS } \\
\begin{array}{l}\text { Log Own- } \\
\text { Income }\end{array}\end{array}$} & \multicolumn{2}{|c|}{ Linear 2SLS } \\
\hline & & $\begin{array}{c}\text { Log } \\
\text { Own- } \\
\text { Income } \\
\end{array}$ & Education & & $\begin{array}{c}\text { Log } \\
\text { Spousal } \\
\text { Income } \\
\end{array}$ & Education & & $\begin{array}{l}\text { Log Own- } \\
\text { Income }\end{array}$ & Education \\
\hline \multirow[t]{2}{*}{ Education } & $0.113^{* * *}$ & $0.190 * * *$ & & $0.061^{* * *}$ & $0.150^{* * *}$ & & $0.056 * * *$ & $0.140 * * *$ & \\
\hline & 0.014 & 0.030 & & 0.014 & 0.034 & & 0.0090 & 0.0210 & \\
\hline \multirow[t]{2}{*}{ Age } & -0.006 & -0.014 & $0.568 * * *$ & 0.036 & 0.03 & $0.568 * * *$ & $0.079 * * *$ & $0.060 * * *$ & $0.543^{* * *}$ \\
\hline & 0.023 & 0.024 & 0.019 & 0.023 & 0.024 & 0.019 & 0.0160 & 0.0170 & 0.018 \\
\hline \multirow[t]{2}{*}{$\begin{array}{l}\text { Age } \\
\text { squared }\end{array}$} & 0.000 & 0.000 & $-0.007 * * *$ & 0.000 & 0.000 & $-0.007 * * *$ & $-0.001 * * *$ & $-0.001 * * *$ & $-0.006 * * *$ \\
\hline & 0.000 & 0.000 & 0.000 & 0.000 & 0.000 & 0.000 & 0.0000 & 0.0000 & 0.000 \\
\hline \multirow[t]{2}{*}{$\begin{array}{l}\text { Family } \\
\text { Owned } \\
\text { Land }\end{array}$} & 0.008 & 0.001 & $0.097 * * *$ & $0.025 * *$ & 0.012 & $0.097 * * *$ & 0.0050 & -0.0060 & $0.125^{* * *}$ \\
\hline & 0.012 & 0.013 & 0.031 & 0.012 & 0.013 & 0.031 & 0.0120 & 0.0120 & 0.032 \\
\hline \multirow[t]{2}{*}{$\begin{array}{l}\text { Father's } \\
\text { education }\end{array}$} & & & $0.188^{* * *}$ & & & $0.188 * * *$ & & & $0.191^{* * *}$ \\
\hline & & & 0.031 & & & 0.031 & & & 0.028 \\
\hline \multirow[t]{2}{*}{$\begin{array}{l}\text { Mother's } \\
\text { education }\end{array}$} & & & $0.256 * * *$ & & & $0.256 * * *$ & & & $0.201 * * *$ \\
\hline & & & 0.031 & & & 0.031 & & & 0.029 \\
\hline \multirow[t]{2}{*}{ Birth order } & & & $0.607 * *$ & & & $0.607 * *$ & & & $0.556 * *$ \\
\hline & & & 0.251 & & & 0.251 & & & 0.232 \\
\hline \multirow[t]{2}{*}{$\begin{array}{l}\text { Male } \\
\text { sibling pct }\end{array}$} & & & $-0.943^{* *}$ & & & $-0.943 * *$ & & & -0.457 \\
\hline & & & 0.371 & & & 0.371 & & & 0.341 \\
\hline \multirow[t]{2}{*}{$\begin{array}{l}\text { Number of } \\
\text { siblings }\end{array}$} & & & $-0.209 * * *$ & & & $-0.209 * * *$ & & & $-0.179 * * *$ \\
\hline & & & 0.028 & & & 0.028 & & & 0.026 \\
\hline $\mathrm{N}$ & 596 & 571 & 2831 & 560 & 537 & 2831 & 1048 & 1016 & 3071 \\
\hline
\end{tabular}

